6. Iribarne A, Schmoker JD, Malenka DJ, Leavitt BJ, McCullough JN, Welder PW et al; Northern New England Cardiovascular Disease Study Group. Does use of bilateral internal mammary artery grafting reduce long-term risk of repeat coronary revascularization? A multicenter analysis. Circulation. 2017;136: 1676-85.

7. Luthra S. Degrees of belief and the burden of proof: the ART Trial. Ann Thorac Surg. 2017;104:1441-4.

8. Gaudino M, Alexander JH, Bakaeen FG, Ballman K, Barili F, Calafiore AM, et al Randomized comparison of the clinical outcome of single versus multiple arterial grafts: the ROMA trial—rationale and study protocol. Eur J Cardiothorac Surg. 2017;52:1031-40.

https://doi.org/10.1016/j.jtcvs.2018.03.094

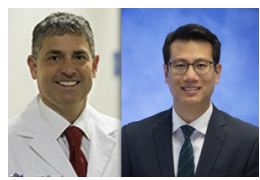

\section{BILATERAL INTERNAL THORACIC ARTERY USE: CLOSING THE KNOWLEDGE GAP Reply to the Editor:}

We thank Saran, Locker, and Joyce $^{1}$ for their letter to the Editor. We are in agreement with many of their points, particularly that the current low use of bilateral internal thoracic artery (BITA) grafts is not due to a nationwide lack of surgical skills. When a surgical professional community is appropriately motivated by compelling scientific evidence, surgical practice can change significantly, as it did for left internal thoracic artery use after the landmark studies of Lytle and colleagues ${ }^{2}$ and Loop and associates ${ }^{3}$ describing the long-term benefits of left internal thoracic artery use.

We believe that the primary reason for the inertia maintaining low BITA use is that a significant knowledge gap still continues to exist with regard to its risks and benefits. We applaud Saran and colleagues ${ }^{4}$ for their analysis of a large propensity-matched cohort of patients at a single institution demonstrating a survival benefit for patients receiving BITA grafts. We maintain, however, that their excellent results may not be reproducible at all hospitals performing coronary artery bypasses nationally.

Saran, Locker, and Joyce are correct that the Arterial Revascularization Trial has only reported midterm 5-year results. ${ }^{5}$ Final 10-year results of the Arterial Revascularization Trial and additional prospective studies, such as the Randomization of Single versus Multiple Arterial Grafts trial, ${ }^{6}$ may help inform us of the true benefits and costs of BITA use.
Authors have nothing to disclose with regard to commercial support.

No one is arguing that a saphenous vein graft is better than a right internal thoracic artery graft in terms of long-term patency. The knowledge gap exists as to whether BITA use will confer a superior long-term survival advantage across a variety of surgical practice environments without increasing the risk of potentially devastating sternal wound infections. Saran and colleagues ${ }^{4}$ have done a laudable job of endorsing their center's positive experience in increasing BITA use. More work must be done, however, to close this knowledge gap and increase BITA utilization nationally.

Terry Shih, MD, MSc ${ }^{a}$
Richard Lee, MD, MBA
University of Michigan
Ann Arbor, Mich
${ }^{a}$ Department of Cardiac Surgery
${ }^{b}$ Center for Comprehensive Cardiovascular Care
Saint Louis University
St Louis, Mo

\section{References}

1. Saran N, Locker C, Joyce DL. Expanding the use of bilateral internal thoracic artery: yes! we can. J Thorac Cardiovasc Surg. 2018;156:1003-4.

2. Lytle BW, Loop FD, Cosgrove FD, Ratliff NB, Easley K, Taylor PC. Long-term (5 to 12 years) serial studies of internal mammary artery and saphenous vein coronary bypass grafts. J Thorac Cardiovasc Surg. 1985;89:248-58.

3. Loop FD, Lytle BW, Cosgrove DM, Stewart RW, Goormastic M, Williams GW, et al. Influence of internal mammary artery graft on 10-year survival and other cardiac events. N Engl J Med. 1986;314:1-6.

4. Saran N, Locker C, Said SM, Daly RC, Maltais S, Stulak JM, et al. Current trends in bilateral internal mammary artery use for coronary revascularization: extending benefit to high-risk patients. J Thorac Cardiovasc Surg. February 22, 2018 [Epub ahead of print].

5. Taggart DP, Altman DG, Gray AM, Lees B, Gerry S, Benedetto U, et al Randomized trial of bilateral versus single internal-thoracic-artery grafts N Engl J Med. 2016;375:2540-9.

6. Gaudino M, Alexander JH, Bakaeen FG, Ballman K, Barili F, Calafiore AM, et al. Randomized comparison of the clinical outcome of single versus multiple arterial grafts: the ROMA trial-rationale and study protocol. Eur J Cardiothorac Surg. 2017;52:1031-40.

https://doi.org/10.1016/j.jtcvs.2018.04.008 